\title{
CANAL SEEPAGE REDUCTION BY SOIL COMPACTION
}

\author{
Charles M. Burt ${ }^{1}$ \\ Monte Soto ${ }^{2}$
}

\begin{abstract}
Canal lining for seepage reduction is extremely expensive. Compaction of soils during the construction of earthen dams is essential for seepage reduction. In an effort to determine if simple in-situ vibratory soil compaction could minimize seepage losses, ITRC conducted large-scale tests on the sides and bottoms of five irrigation district earthen canal. When the sides and bottoms were compacted, reductions of about $86 \%$ were obtained; reductions of 12 - 31\% were obtained when only sides were compacted.
\end{abstract}

\section{INTRODUCTION}

Irrigation districts that rely upon long, open canals share a common problem: canal seepage. Canal seepage can create difficulties including:

- Reduced water deliveries to farmers

- Increased pumping costs if the water in the canals is lifted by pumps

- Increased drainage problems, possibly causing crop yield and health problems

- Loss of water supply in a basin if the seepage goes to a salty aquifer or into the ocean

- Increased diversion from rivers, resulting in decreased in-stream flows

The two most common solutions for reducing seepage are lining canals or replacing them with pipes. These options bring along with them additional benefits, such as stabilization of banks (with canal lining) or reduced need for access and fewer drownings (with pipelines). However, these solutions are expensive. A typical piping cost in California for an irrigation district is in the neighborhood of $\$ 120-\$ 300 /$ foot for pipe sizes in the 4 feet to 5 feet diameter range (flows in the 20-30 cubic feet per second [CFS] range). Canal lining costs are often in the neighborhood of $\$ 1$ million per mile, which is prohibitive for most irrigation districts. A medium-sized district may have more than 100 miles of unlined canals.

The general concepts of soil compaction for seepage reduction and soil consolidation are well documented in civil engineering, under the category of "soil mechanics". Everyone is familiar with compaction of soils for roadways, even if they do not understand the technical details. New canal bases are often compacted using standard engineering techniques. But most canals were crudely built, and we have never seen any attempts in the US to reduce seepage by running compaction equipment over the canal surfaces (without doing the standard over-excavation of soil and careful compaction of replaced soil in layers). Therefore, the Irrigation Training and Research Center (ITRC), with support from CALFED and the California Agricultural Research Initiative, conducted

\footnotetext{
${ }^{1}$ Professor of Irrigation, BioResource and Agricultural Engr. Dept.; Chairman, Irrigation Training and Research Center, California Polytechnic State Univ., San Luis Obispo, CA 93407 cburt@calpoly.edu

${ }^{2}$ Engineer, ITRC; msoto@calpoly.edu
} 
some research to evaluate the effectiveness of in-place compaction of canal banks and canal bottoms in reducing canal seepage.

\section{Concepts of Soil Compaction}

First, two of the major dams in California (Oroville Dam and San Luis Dam) are earthfilled dams rather than concrete structures. Obviously, proper soil compaction can reduce seepage.

Soil laboratory tests for compaction (Proctor and Modified Proctor) have specified procedures by ASTM. Samples of soil are compacted in specified layer thicknesses, with specified weights dropped a specified number of times from a specified height. In a compaction test, this is typically done with a number of samples, each having a different soil moisture content. A graph such as Figure 1 is developed, illustrating what the moisture content should be during construction. The purpose of this compaction is generally to build a solid soil foundation that will not settle over time, or which will not deflect when subjected to transient loads. Seepage reduction is not a typical goal except for dams.

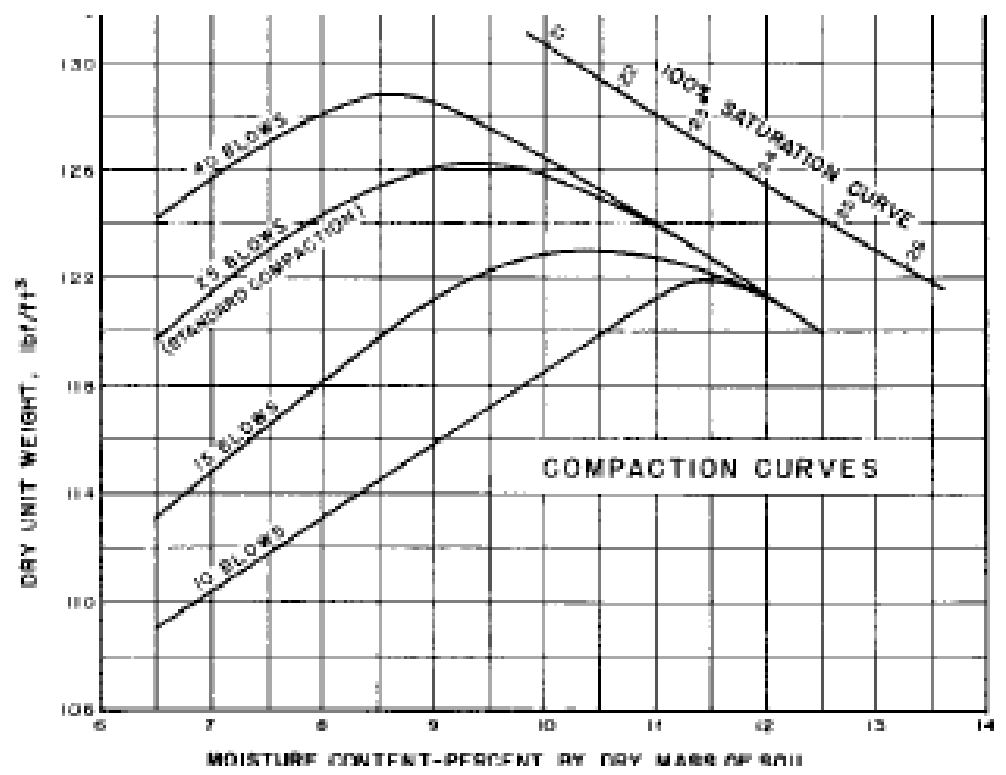

Figure 1. Compaction curves (USBR, 1998)

Some soils compact better than others and as the level of compaction increases, the soil hydraulic conductivity (seepage rate) decreases. Optimum compaction for a high bulk density will also depend upon the moisture content during compaction (see Figure 1). If the soil is too moist or too dry, it will not achieve the "optimum bulk density".

The details of compaction are more complex than indicated by Figure 1 alone. The optimum moisture content is not only dependent on soil type/gradation; it also depends upon the amount of energy applied to the soil for compaction purposes. Therefore, different laboratory compaction test procedures yield different results. The Standard Proctor Optimum Moisture Content (SPOM) varies considerably from the Modified 
Proctor Optimum Moisture Content for the same soil. Further, energy levels (hammer mass, drop height, and number of drops) applied in determining SPOM and MPOM are arbitrary in nature. The Standard Proctor test was developed in the 1920s when static rollers were state-of-the-art. The Modified Proctor test was developed in the 1950s and reflected the increased compaction capabilities of vibratory compactors. Today, technology has advanced even further in terms of energy applied by at least a few compactors, including vibration speeds, pressure, and configuration of the pads/rollers. In general, the higher the applied energy, the lower optimum moisture content will be.

The optimum moisture content for high bulk density cannot necessarily be converted into the optimum moisture content for reduced seepage. Some engineers believe that a slightly-moister-than-“optimum” soil in the field provides the best seepage reduction for non-clay soils.

There are challenges here for in-situ compaction for seepage reduction.

1. Normally one only has a small window of time during which the canals are "dry". Because clay soils can liquefy during compaction if they are too wet, clay soils should probably be compacted at moisture contents slightly below the "optimum" moisture content - if the objective is seepage reduction. It is extremely difficult to dry a clay soil to below the "optimum" moisture range. Therefore, it is extremely difficult to properly compact clay soils. On the plus side, usually the clay soils have low seepage rates. On the negative side, what small amounts of water do seep out often show up on the surface of the soil next to the canal and create operational headaches for farmers and district personnel.

2. If one applies a laboratory compaction test (at various moisture contents) to a soil, it is fairly easy to determine differences in bulk density, as illustrated in Figure 1. It is entirely different in determining the effect on hydraulic conductivity. Over a wide range of compaction conditions, the laboratory tests will yield very similar results - a drastic reduction of hydraulic conductivity. To look at the lab results, one could conclude that as long as there is some compaction the seepage would almost be eliminated. It doesn't turn out quite that good in the field.

3. A canal is removed from service for a few weeks, perhaps, prior to compaction. That means at each depth from the surface, there is a different moisture content.

Table 1 indicates that the best type of compaction equipment will vary, depending upon the soil type.

Table 1. Compaction equipment (Bader, 2001)

\begin{tabular}{|c|c|c|c|c|}
\hline \multicolumn{5}{|c|}{ Effect of Soil Type on Equipment selection } \\
\hline & & $\begin{array}{l}\text { Vibrating Sheepsfoot } \\
\text { Rammer }\end{array}$ & $\begin{array}{l}\text { Static Sheepsfoot } \\
\text { Smooth Roller }\end{array}$ & $\begin{array}{l}\text { Vibrating Plate } \\
\text { Vibrating Roller }\end{array}$ \\
\hline & Lift Thickness & Impact & Pressure & Vibration \\
\hline Gravel & $12 \mathrm{in.}$ & Poor & No & Good \\
\hline Sand & $10 \mathrm{in.}$ & Poor & No & Excellent \\
\hline Silt & 6 in. & Good & Good & Poor \\
\hline Clay & 6 in. & Excellent & Very Good & No \\
\hline
\end{tabular}


Table 1 does not cover all possible choices of equipment. For the compaction research, ITRC purchased a Universal Vibratory Wheel (UVW) Roller from MBW, Inc. This is a sheepsfoot in-drum configuration. The operator can select the mode of vibration for a particular condition. It can be operated in static mode (clays), vibratory mode (little host machine down pressure, for sands and gravels), and in a mode that combines variable host machine down pressure to a maximum of roughly 30,000 lbs. (at the end of an excavator arm) with full vibration (clays, mixed soils, most native soils).

\section{Soil Compaction for Sealing Canals}

Perhaps the best source for information on earth lining of canals is a publication by ANCID (Australian National Committee on Irrigation and Drainage, 2001) entitled “Open Channel Seepage and Control”. This publication, as well as others, focuses on bringing soil material to the site one layer at a time and properly compacting each layer. The publication does mention "in situ" compaction - which is in-place compaction of existing canal banks and bottoms. The senior author has talked to engineers from dozens of irrigation districts in California about this, and has not encountered anyone who has tried in-situ compaction before this research - which seems difficult to believe but seems to be the case.

\section{FIELD EXPERIMENTS IN CALIFORNIA}

ITRC contacted four irrigation districts in the San Joaquin Valley of California which were experiencing seepage problems:

- Panoche WD

- Chowchilla WD

- $\quad$ San Luis Canal Co. (also known as Henry Miller Reclamation District)

- James ID

Seepage tests were conducted on two Panoche WD canals, and it was determined that the seepage rates were very low. Plus, the soil was a heavy silty clay loam and it was impossible to dry the soil out enough for compaction without just making mud.

The other three districts had sandier soil, so compaction trials were conducted there. The results of one canal compaction effort in Chowchilla cannot be reported because the well that would have supplied the water for post-compaction seepage tests failed and was not repaired.

All the compaction work was "in-situ", meaning that there was no addition of soil, and no over-excavation and replacement of compacted soil layers. The compaction was performed on the soil surface "as-is" with the exception of some smoothing of canal banks.

Seepage Tests. Prior to and after compaction, ponding tests were conducted to determine the seepage rates. The ponding tests involved the following: 
- The entire canal pool that was compacted was filled with water to the normal operating depth.

- The ends of the pool were sealed to prevent water from entering or leaving the pool.

- Weather data was recorded from the nearest CIMIS station, to estimate evaporation losses.

- Redundant water level sensors were installed to measure the change in water depth versus time.

- The water was replenished occasionally with a metered supply to maintain a fairly constant water level.

- Water temperatures were measured, to correct for different viscosities in pre- and post-compaction tests.

- Measurements began after water had been standing in the pool for several days, and continued for 1-3 days.

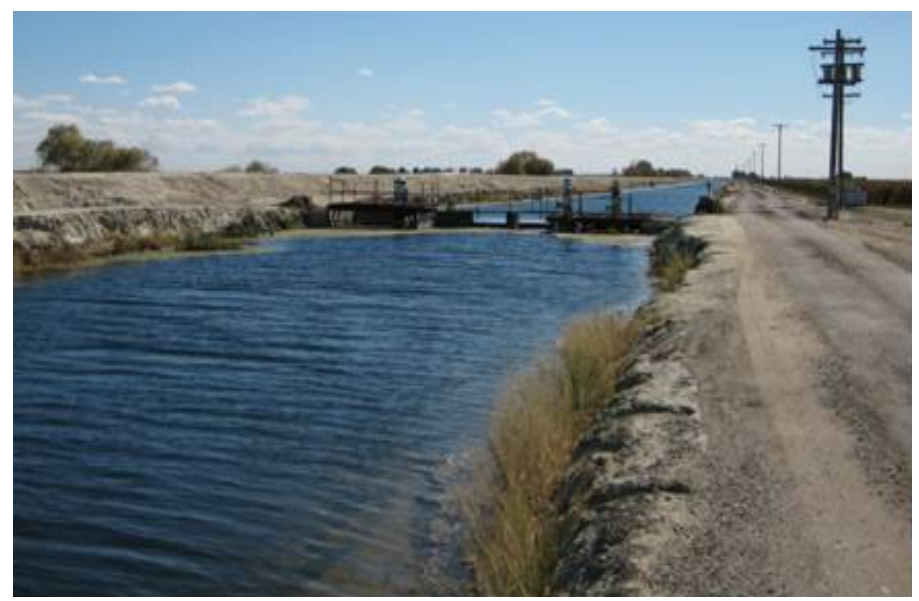

Figure 2. James ID Main Canal during pre-compaction seepage test

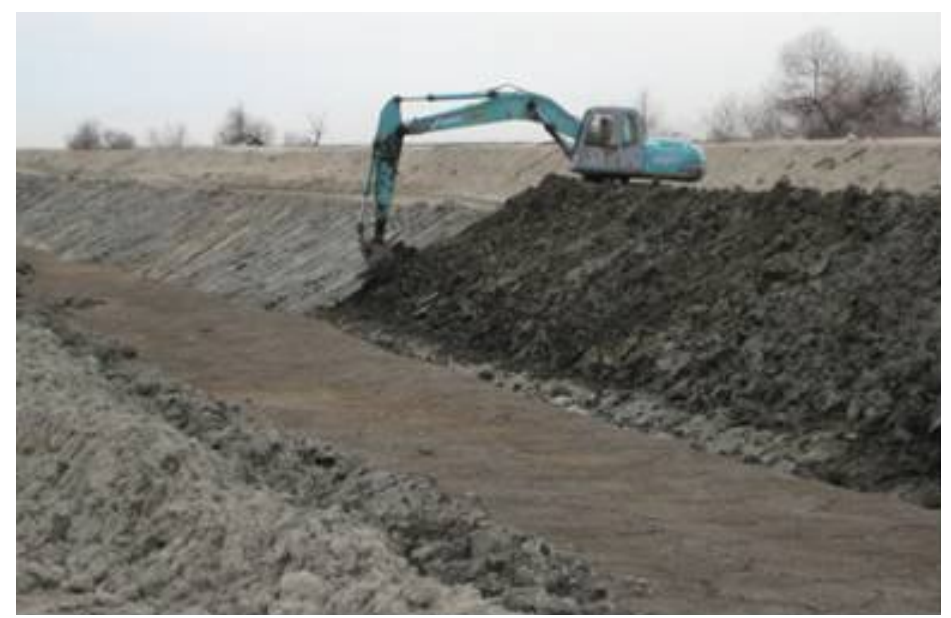

Figure 3. James ID Main Canal during side compaction 


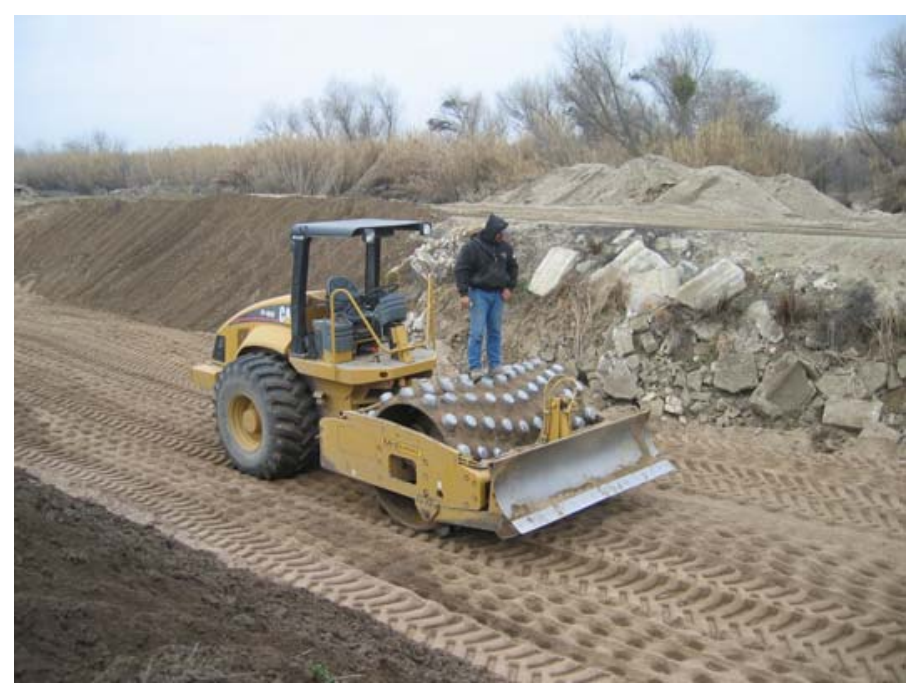

Figure 4. Ride-on vibratory compactor for bottom of canals.

Henry Miller Reclamation District Swamp 1 Ditch PRE Compaction DRUCK Data

- ITRC $014-$ ITRC 021

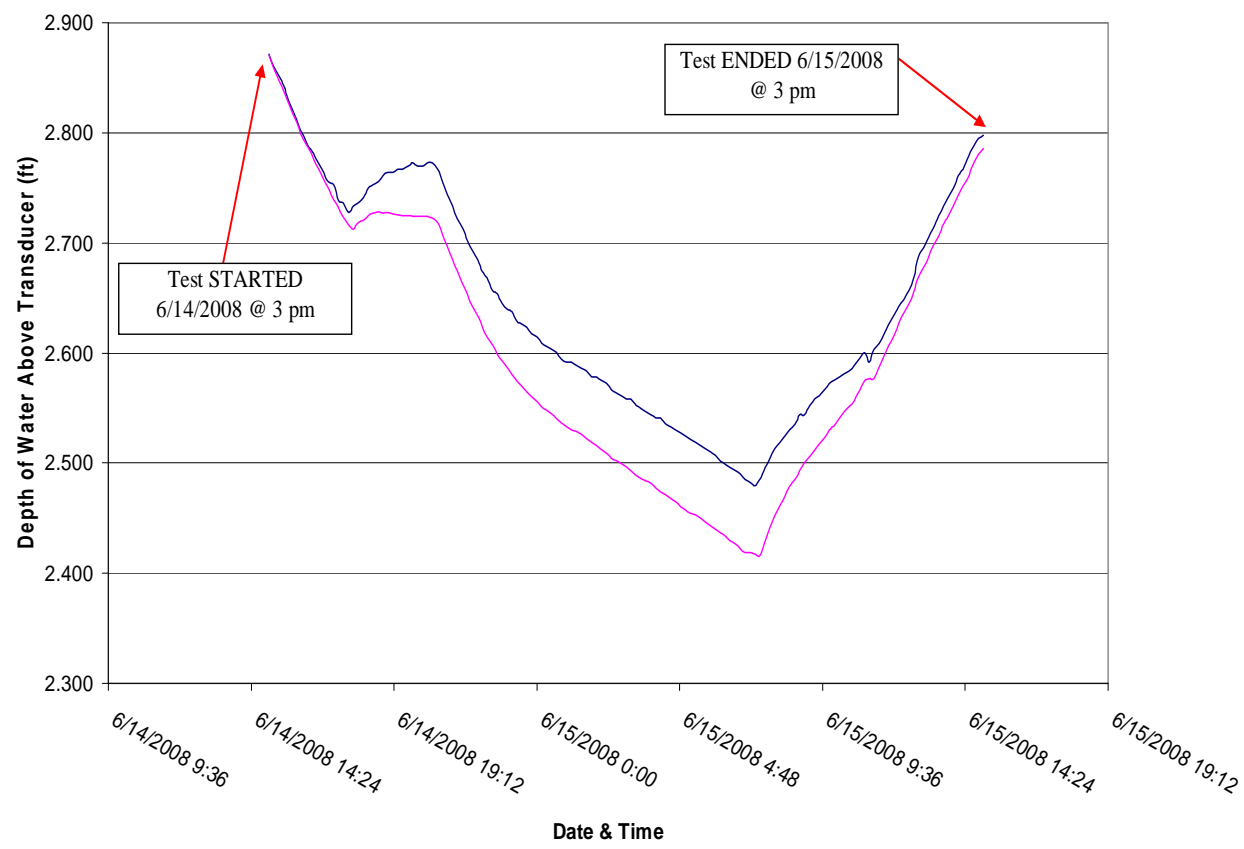

Figure 5. Pressure transducer ("Druck” brand) data for ponding test - San Luis Canal Co (Henry Miller RD)

Soil Preparation. During the first compaction work at Lateral H in James ID, it was learned that if the canal banks were first smoothed off, the compactor could operate much more quickly. Subsequent locations were therefore lightly smoothed off. There was no opportunity to obtain the "optimum" moisture content for compaction. Field conditions and availability required that the compactor begin work as soon as the canal had dried down enough to use the equipment without making mud. Certainly, moisture contents were different at various depths in the banks and bottom. 
Laboratory Tests. Soil samples were taken in the field for a number of reasons. In some cases, undisturbed core samples were taken to measure bulk density before and after compaction. Texture samples (about 20 per canal section) were taken at various depths. Laboratory experiments were run with the Modified Proctor test to determine optimum lab moisture contents for compaction, and the effects on hydraulic conductivity. As noted earlier, the hydraulic conductivity measurements were inconclusive except to show that any amount of compaction drastically reduced to the hydraulic conductivity in the lab.

Equipment and Costs. The side soil was compacted using a 45-thousand pound Kobelco excavator with an MBW, Inc. UVW 36-inch roller attached to the end of the boom. Installed immediately between the UVW-36 roller and the end of the excavator boom was a UV-10K exciter. This exciter is a hydraulically driven vibration mechanism. Since the vibratory exciter was hydraulically driven, the excavator operator could engage and disengage the exciter when he felt it was necessary. For large canal bottoms, a rideon unit was used (Fig. 4)

The compaction accessories cost about $\$ 25,000$ (not including the cost of the excavator) installed. An experienced operator was able to compact the sides of 1 mile of canal (both sides, meaning 2 miles total) in about 8 days. The cost for the operator, transport of the excavator, and the excavator rental was about $\$ 1.20$ /foot of canal, with about 10 feet of compaction on each side of the canal (cost $=\$ 1200$ for 1000 ’ long pool).

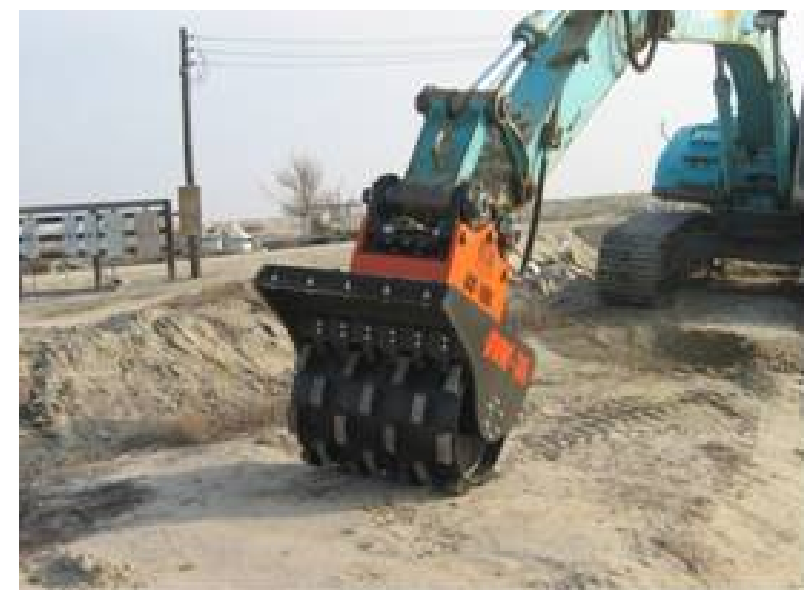

Figure 6. 36” vibratory roller (MBW, Inc.) attached to the end of an excavator arm. 


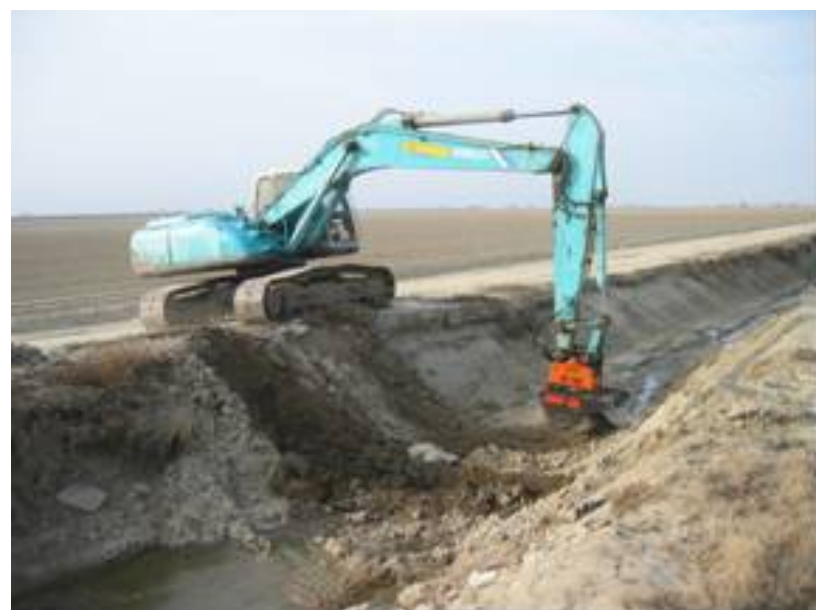

Figure 7. Compacting the sides and bottom of Lateral $\mathrm{H}$ at James ID

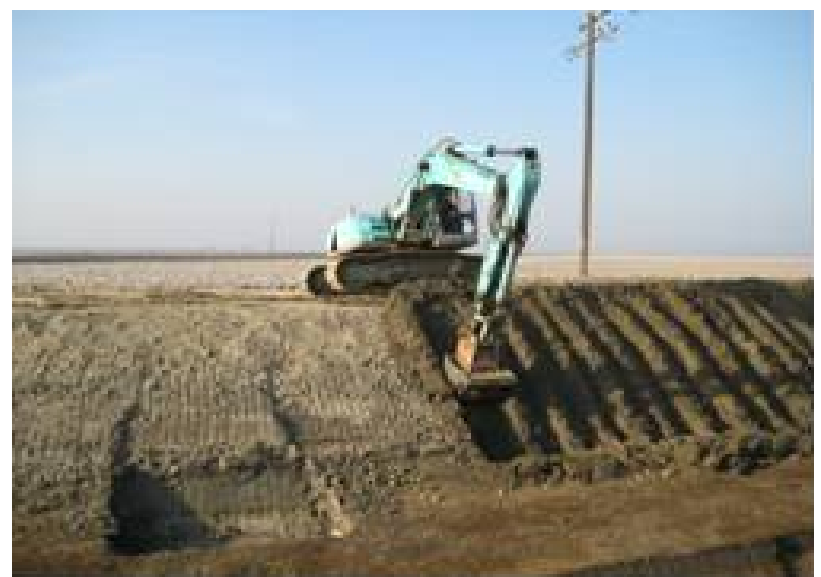

Figure 8. Compacting the canal banks on the James ID main canal with an MBW vibratory roller

\section{RESULTS}

Table 2 shows the results of the in-situ compaction. Seepage reduction varied from $12 \%$ to $89 \%$. Clearly, the three sites at which the canal bottom was compacted had much better results than the two sites at which only the sides were compacted. The seepage differences were probably due to additional factors, but this appears to be one possible explanation. 
Table 2. Compaction results

\begin{tabular}{|c|c|c|c|c|c|c|c|c|c|c|}
\hline \multirow{2}{*}{$\begin{array}{l}\text { Irrigation } \\
\text { District }\end{array}$} & \multirow{2}{*}{ Location } & \multicolumn{2}{|c|}{ Compaction } & \multirow{2}{*}{$\begin{array}{l}\text { Cost } \\
\$\end{array}$} & \multirow{2}{*}{$\mathrm{L}, \mathrm{ft}$} & \multirow{2}{*}{$\begin{array}{l}\text { Canal } \\
\text { width, } \\
\mathrm{ft}\end{array}$} & \multirow{2}{*}{ Texture } & \multirow{2}{*}{$\begin{array}{l}\text { Pre- } \\
\text { Seepage } \\
\text { GPM }\end{array}$} & \multirow{2}{*}{$\begin{array}{l}\text { Post- } \\
\text { Seepage } \\
\text { GPM }\end{array}$} & \multirow{2}{*}{$\begin{array}{c}\% \\
\text { Seepage } \\
\text { Reduction }\end{array}$} \\
\hline & & Sides & Bottom & & & & & & & \\
\hline $\begin{array}{c}\text { Chowchilla } \\
\text { WD }\end{array}$ & $\begin{array}{l}\text { Site } \# 2- \\
\text { Ash Main } \\
\text { Canal, } \\
\text { between } \\
\text { roads } 11-12\end{array}$ & Y & $\mathrm{N}$ & 4,845 & 4,240 & 27 & $\begin{array}{l}\text { Loamy } \\
\text { Sand }\end{array}$ & 143 & 126 & $12^{*}$ \\
\hline James ID & $\begin{array}{c}\text { Lateral } \mathrm{H} \text {, } \\
\text { from Main } \\
\text { Canal to TO }\end{array}$ & Y & Y & 3,240 & 1,010 & 15 & $\begin{array}{l}\text { Sandy } \\
\text { Loam }\end{array}$ & 86 & 12 & 86 \\
\hline James ID & Main Canal & Y & $N$ & 15,800 & 10,238 & 58 & $\begin{array}{l}\text { Sandy } \\
\text { Loam }\end{array}$ & 252 & 173 & 31 \\
\hline $\begin{array}{l}\text { San Luis } \\
\text { Canal Co. }\end{array}$ & $\begin{array}{l}\text { Swamp } 1 \\
\text { Ditch, } \\
\text { between } \\
\text { Turner } \\
\text { Island \& } \\
\text { Deep Well }\end{array}$ & Y & Y & 1,945 & 1,730 & 27 & $\begin{array}{l}\text { Sandy } \\
\text { Loam }\end{array}$ & 130 & 14 & 89 \\
\hline $\begin{array}{l}\text { San Luis } \\
\text { Canal Co. }\end{array}$ & $\begin{array}{l}\text { East Delta } \\
\text { Canal }\end{array}$ & $\mathrm{Y}$ & $\begin{array}{c}Y \text { - with } \\
\text { ride- } \\
\text { on }^{\star *}\end{array}$ & 3,100 & 3,020 & 19 & Loam & 80 & 8 & 90 \\
\hline
\end{tabular}

*The Chowchilla WD site had sections of rip-rap along the canal banks that could not be compacted, resulting in a lower $\%$ seepage reduction

** Ride-on indicates a large self-propelled unit

\section{CONCLUSION}

For sandy loam soils, in-situ compaction with a vibratory roller reduced seepage. The seepage reduction was significant $(86-89 \%)$ when both the sides and bottom were compacted. The compaction extended to a depth of about 2 feet, so it is anticipated that the seepage reduction will withstand normal maintenance activities from year to year.

\section{REFERENCES}

ANCID. 2001. Open Channel Seepage and Control, Vol. 2.1. Australian National Committee on Irrigation and Drainage. March 2001

Bader, C.D. 2001. Soil compaction: Modern solutions to an age-old need. Forester Media, Inc. http://www.forester.net/gx_0101_compaction.html. <Verified 9/30/2008>

USBR. 1998. Earth Manual - Part I. $3^{\text {rd }}$ Edition. United States Department of the Interior, Bureau of Reclamation. Earth Sciences and Research Laboratory - Geotechnical Research Technical Service Center, Denver, CO. Also at http://www.usbr.gov/pmts/writing/earth/earth.pdf. <Verified 2/12/2009> 